\title{
PELINDUNGAN HAK PILIH PENYANDANG DISABILITAS MENTAL DALAM PENDEKATAN RANGKAIAN PROSES PASCA PUTUSAN MAHKAMAH KONSTITUSI NOMOR 135/PUU-VIII/2015
}

\section{PERSONS WITH MENTAL DISABILITIES RIGHTS TO VOTE PROTECTION WITH CONTINUUM APPROACH POST OF CONSTITUTIONAL COURT DECISION NUMBER 135/PUU-VIII/2015}

\author{
Fajri Nursyamsi \\ Sekolah Tinggi Hukum Indonesia Jentera; Puri Imperium, Office Plaza, Lantai UG \\ 11. Kuningan Madya, Jakarta, 12980 \\ fajri.nursyamsi@jentera.ac.id) \\ Muhammad Nur Ramadhan \\ Badan Pengawas Pemilihan Umum Republik Indonesia (Bawaslu RI); Jl. \\ M.H.Thamrin Nomor 14, Gondangdia, Menteng \\ mnr.mnuramadhan@gmail.com)
}

\begin{abstract}
The Constitutional Court Decision Number 135 / PUU-XIII / 2015 stated that the requirement for "not being mentally / memory disturbed" to be registered as a voter in Law Number 8 of 2015 is unconstitutional. The decision opens a new perspective on the protection of suffrage for persons with mental disabilities, and acknowledges that mental / memory impairment conditions are not the same between one person and another. The decision is in accordance with the development of thoughts on the legal capacity of persons with disabilities using a continuum approach, which recognizing that everyone is a legal subject, but practically it is necessary to look at the person's ability to exercise their rights, especially in decision making. The Constitutional Court decision has been applied in various regulations related to elections, which cannot be separated from the efforts of disabled people organizations to implement it. However, the changes are still at the administrative level, have not resulted in a change in perspective on the recognition of the legal capacity of persons with mental disabilities. In
\end{abstract}


practice, there are still cases of persons with mental disabilities who were not registered as voters so that they are forced to be unable to exercise their voting rights. Based on this explanation, it is important to analyze how the legal capacity approach for persons with mental disabilities is used in the Constitutional Court decisions Number 135 / PUU-XIII / 2015, and how this approach should be applied to ensure the protection of the suffrage rights of persons with disabilities. This legal research was conducted using a qualitative approach, using primary sources of law in the form of statutory regulations and other forms of policy, as well as secondary sources of law in the form of literature and other valid and relevant information. This study presents a discussion of the suffrage rights of persons with mental disabilities using a continuum approach that has not been discussed in previous studies, so that it is expected to be able to sharpen the implementation.

Keywords: Persons with Mental Disabilities, rights to vote, general election, local election, continuum approach.

\section{Abstrak}

Putusan Mahkamah Konstitusi Nomor 135/PUU-XIII/2015 menyatakan bahwa syarat "tidak sedang terganggu jiwa/ingatannya" untuk didaftar menjadi pemilih dalam Undang-Undang Nomor 8 tahun 2015 adalah inkostitusional. Putusan ini membuka perspektif baru terhadap pelindungan hak pilih bagi penyandang disabilitas mental, dan mengakui bahwa kondisi terganggu jiwa/ingatan tidaklah sama antara satu orang dengan orang lainnya. Putusan Mahkamah Konstitusi sesuai dengan perkembangan pemikiran tentang kapasitas hukum penyandang disabilitas dengan pendekatan continuum, yaitu mengakui bahwa setiap orang adalah subyek hukum, tetapi secara praktis tetap perlu melihat kepada kemampuan orang tersebut untuk menggunakan haknya, terutama dalam pengambilan keputusan. Putusan Mahkamah Konstitusi itu sudah diterapkan dalam berbagai regulasi terkait dengan Pemilu, yang tidak dapat dilepaskan dari upaya organisasi penyandang disabilitas untuk mengimplementasikannya. Namun perubahan yang terjadi masih berada dalam level administratif, belum berdampak pada perubahan cara pandang terhadap pengakuan kapasitas hukum penyandang disabilitas mental. Dalam praktiknya masih ditemukan kasus penyandang disabilitas mental yang tidak didaftar sebagai pemilih sehingga terpaksa tidak dapat menggunakan hak pilihnya. Bedasarkan penjelasan itu penting untuk menganalisa bagaimana pendekatan kapasitas hukum bagi penyandang disabilitas mental yang digunakan dalam Putusan Mahkamah Konstitusi, dan bagaimana pendekatan itu harus diterapkan untuk menjamin pelindungan hak pilih penyandang disabilitas. Penelitian hukum ini dilakukan dengan pendekatan kualitatif, dengan menggunakan sumber hukum primer berupa peraturan perundang-undangan dan bentuk kebijakan lainnya, serta 
sumber hukum sekunder berupa literatur dan informasi lain yang valid dan relevan. Penelitian ini menyajikan pembahasan mengenai hak pilih penyandang disabilitas mental dengan pendekatan continuum yang belum dibahas dalam penelitian sebelumnya, sehingga diharapkan mampu mempertajam upaya implementasinya di lapangan.

Kata Kunci: Penyandang Disabilitas Pendekatan Continuum.

\section{Pendahuluan}

Putusan Mahkamah Konstitusi (MK) Nomor 135/PUU-VIII/2015 (Putusan MK 135) membawa perspektif baru dalam pelindungan hak pilih penyandang disabilitas mental di Indonesia. Putusan ini mengakui bahwa kondisi terganggu jiwa/ingatannya adalah tidak dapat disamakan antara satu orang dengan orang lainnya, sehingga tidak dapat menjadi syarat untuk mendaftar seseorang menjadi pemilih dalam Pemilihan Umum (Pemilu) dan Pemilihan Kepala Daerah (Pilkada). Putusan MK 135 memberikan peran besar dalam upaya negara memberikan pengakuan terhadap kapasitas hukum orang dengan disabilitas mental, sekaligus melindung hak pilihnya.

Perubahan yang dibawa oleh Putusan MK 135 selaras dengan perubahan yang juga terjadi pada instrumen hukum internasional dalam memaknai hak pilih bagi penyandang disabilitas mental. Dalam konsep Hak Asasi Manusia (HAM), hak pilih merupakan bagian dari hak sipil politik yang tercantum dalam Konvensi Internasional Hak Sipil dan Politik (International Convention of Civil and Politic Rights - ICCPR). Pada awalnya, ICCPR memasukan kondisi gangguan jiwa sebagai alasan untuk membatasi hak pilih penyandang disabilitas
Mental, Hak Pilih, Pemilu, Pilkada,

mental (derogable rights). Namun setelah pengesahan Konvensi Hak Penyandang Disabilitas (Convention on The Rights of Persons with Disabilities (RPD), maka hak pilih bagi penyandang disabilitas menjadi tidak dapat dibatasi. Bahkan negara wajib untuk menghilangkan sejumlah hambatan pelaksanaan hak pilih penyandang disabilitas, yang berpotensi membatasi atau menghilangkan hak pilih bagi penyandang disabilitas. Dalam konteks hak pilih bagi penyandang disabilitas mental, kewajiban negara adalah mengakui kapasitas hukum, dan berupaya mendukung agar penyandang disabilitas mental mampu untuk mengambil keputusan sendiri secara mandiri.

Selain hal tersebut, Putusan MK 135 juga selaras dengan pendekatan continuum (rangkaian proses) dalam menilai kapasistas hukum seorang penyandang disabilitas. Dalam pendekatan ini penyandang disabilitas diakui sebagai subyek hukum, atau pihak yang memiliki hak, tetapi untuk penggunaan haknya perlu dilakukan penilaian, terutama terkait dengan kemampuan pengambilan keputusan. Putusan MK 135 menjadi contoh peran aktif negara dalam menghilangkan hambatan bagi penyandang disabilitas mental untuk memiliki dan menggunakan hak pilihnya, terutama 
dalam aspek regulasi. Putusan MK 135 menyatakan syarat "tidak sedang terganggu jiwa/ingatannya" untuk terdaftar sebagai pemilih dalam Pemilu/Pilkada, yang tercantum dalam Pasal 57 ayat (3) huruf a UndangUndang Nomor 8 Tahun 2015 sebagai suatu norma yang inkonstitusional. Putusan MK 135 itu kemudian menjadi rujukan dalam pembentukan UU maupun Peraturan Komisi Pemilihan Umum (KPU) untuk menghilangkan syarat "tidak sedang terganggu jiwa/ ingatannya" dalam mendaftar Pemilih pada Pemilu/Pilkada.

Namun begitu, dalam praktiknya masih ada penyandang disabilitas mental yang tidak didaftar sebagai pemilih dalam Pilkada 2017 dan 2018, serta Pemilu 2019. Hal itu terjadi karena penyandang disabilitas mental masih dianggap bukan subyek hukum sekaligus tidak mampu untuk mengambil keputusan secara mandiri, terutama dalam melaksanakan hak pilinnya. Praktik itu tidak selaras dengan pendekatan rangkaian proses yang sudah digunakan dalam Putusan MK 135, karena dalam praktik tersebut pendekatan yang dilakukan lebih tepat dikatakan sebagai pendekatan "All or Nothing", yaitu menyeragamkan penyandang disabilitas sebagai pihak yang tidak memiliki hak, sehingga secara otomatis dianggap tidak dapat melaksanakan atau menggunakan haknya tersebut, termasuk hak pilih dalam Pemilu/Pilkada.

Apabila mengambil contoh dari negara lain misalnya di Amerika Serikat, di setiap negara bagiannya memastikan setiap penduduk dengan disabilitas dapat mendaftarkan diri sebagai pemilih dalam Pemilu
Presiden yang diselenggarakan pada 2020 saat ini. Selain itu, praktik baik lainnya adalah menyediakan layanan asistensi bagi penyandang disabilitas, termasuk penyandang disabilitas mental, apabila memerlukan dukungan secara spesifik sesuai kebutuhan untuk menggunakan hak pilihnya. Keseluruhan layanan itu diinformasikan melalui website yang mudah diakses, yaitu di North Carolina (https://www.ncsbe.gov/voting/helpvoters-disabilities, diakses pada 5 November 2020), di Alabama (https:// www.sos.alabama.gov/alabamavotes/voter/assistance-disability, diakses pada 5 November 2020), dan di Washington (https://www. disabilityrightswa.org/publications/ assisting-voters-disabilities/ diakses pada 5 November 2020). Sementara itu di Australia, layanan pendampingan juga tersedia untuk Pemilu yang akan diselenggarakan pada 2021. Pendamping yang akan memberikan informasi terkait kepemiluan atau kebutuhan lain yang diperlukan untuk mendukung penggunaan hak pilih dapat berasal dari petugas penyelenggara Pemilu atau kandidat lain yang dipilih sendiri oleh penyandang disabilitas, sehingga dapat memberikan kenyamanan dalam memberikan pelayanan (https://www. aec.gov.au/assistance, diakses pada 5 November 2020).

Berdasarkan penjelasan tersebut, Penulis bermaksud menulis artikel yang menjelaskan bagaimana Putusan MK 135 menjamin hak memilih bagi penyandang disabilitas dan advokasi apa saja yang telah dilakukan agar penyandang disabilitas dapat menggunakan hak memilihnya, 
serta untuk mengetahui bagaimana upaya yang harus dilakukan oleh penyelenggara Pemilu/Pilkada, dalam rangka menjalankan Putusan MK 135 sesuai dengan pendekatan yang digunakan dalam memandang kapasitas hukum bagi penyandang disabilitas mental.

Dari hasil pembacaan dan perbandingan, ada 3 poin kebaruan daripenelitian ini dibandingkan dengan penelitian-penelitian yang sudah ada. Pertama, Penelitian-penelitian yang sudah ada mendasarkan hak pilih penyandang disabilitas hanya kepada ketentuan dalam Konvensi Internasional Hak Sipil Politik (International Convention on Civil and Political Rights - ICCPR) dan CRPD seperti misalnya penelitian berjudul "Peran Progresif Mahkamah Konstitusi dalam Melindungi Hak Pilih Disabilitas Kategori Orang Dengan Gangguan Jiwa dan Pengaruhnya Terhadap Peningkatan Partisipasi Pemilih dalam Pemilu" (Anggono dan tim penyusun, 2019), sedangkan penelitian ini akan merujuk juga kepada prinsip-prinsip dalam komentar umum, baik ICCPR maupun CRPD, serta menjabarkan dinamika diantara keduanya; Kedua, penelitian ini akan membahas prinsip pengakuan terhadap kapasitas hukum penyandang disabilitas dan pendekatan supported decision making dalam konteks Pemilu/Pilkada di Indonesia, sedangkan penelitian yang ada sebelumnya hanya menjabarkan perihal prinsip supported decision making tetapi belum dikaitkan dengan hak pilih dalam Pemilu, seperti dalam penelitian berjudul "Asesmen Hukum Pengampuan Indonesia: Perlindungan Hak Orang dengan Disabilitas
Psikososial" (LBHM, 2020); dan Ketiga, penelitian ini tidak hanya melihat teks perubahan regulasi seperti pada penelitian berjudul "Hak Pilih Bagi Penyandang Disabilitas Mental Ditinjau dari Perspektif Hak Asasi Manusia" (Rahmanto, 2019), tetap akan disertai dengan konteks advokasi yang dilakukan oleh organisasi penyandang disabilitas, yang berdampak terhadap perubahan-perubahan tersebut.

\section{Metode Penelitian}

Penelitian ini merupakan penelitian hukum normatif (yuridis normative) atau doktrinal, yakni penelitian yang diterapkan khusus pada ilmu hukum (Istanto, 2007). Penelitian ini dilakukan dengan cara menguji dan mengkaji data sekunder berupa hukum positif, asas-asas teori hukum, serta kaidah-kaidah hukum yang berhubungan dengan Kepemiluan, Hak Asasi Manusia dan bidang ilmu lain yang berkaitan dengan hak pilih penyandang disabilitas mental. Penelitian ini juga bersifat deskriptif analitis yang bertujuan untuk menggambarkan dan menganalisis temuan-temuan penelitian secara sistematis, faktual, dan akurat dengan teori-teori hukum positif yang menyangkut permasalahan yang diteliti (Sumardjono, 1989, hlm. 23).

Obyek penelitian akan dianalisa dengan menggunakan peraturan perundang-undangan dan putusan pengadilan, serta akan dilengkapi dengan pendekatan konseptual yang berangkat dari suatu konsep hukum yang diajukan baik secara filsafat, asas ataupun teori hukum yang ada (Marzuki, 2006, hlm. 133). 
Penelitian ini mendapatkan data dan informasi berdasarkan teknik studi kepustakaan (library research), studi internet (online research) dan studi lapangan (field research). Jenis data yang digunakan dalam penelitian ini adalah data primer yang berasal dari wawancara dan data sekunder berupa literatur yang relevan. Wawancara dilakukan terhadap penyelenggara Pemilu/Pilkada di tingkat nasional dan daerah untuk mendapatkan informasi terkait dengan kebijakan teknis dan pelaksanaan penghormatan pelindungan hak pilih penyandang disabilitas mental di lapangan, terutama pasca Putusan MK 135. Wawancara juga dilakukan terhadap Ketua dari Organisasi Penyandang Disabilitas mental yang aktif dalam advokasi isu hak pilih penyandang disabilitas mental, untuk mendapatkan informasi dan pengalaman mereka dalam melaksanakan advokasi, sekaligus sebagai bentuk partisipasi langsung penyandang disabilitas dalam penelitian ini sebagai perwujudan dari prinsip nothing about us without us yang diusung dalam CRPD. Data sekunder terdiri dari bahan hukum primer, yaitu data utama dan autentik seperti peraturan perundangundangan dan putusan pengadilan; dan bahan hukum sekunder, yaitu data yang mengutip dari sumber lain sehingga tidak bersifat autentik lagi, seperti literatur hukum dan pemberitaan di media.

Dalam penelitian ini juga dilakukan studi terhadap penelitian-penelitian terdahulu dengan lingkup tema yang serupa. Berdasarkan penelusuran, terdapat berbagai publikasi penelitian yang menganalisa Putusan MK 135. Penelitian-penelitian itu menganalisa secara mendalam Putusan MK dari berbagai perspektif, baik yang bernada pro atau kontra.

\section{Perspektif Teori Tentang Kapasitas Hukum \\ Kapasitas hukum atau legal} capacity dapat dipahami sebagai kemampuan atau kemungkinan seseorang untuk bertindak dalam kerangka sistem hukum (Commissioner for Human Right, 2012, hlm. 7). Kapasitas hukum juga dapat dimaknai sebagai kondisi dimana setiap manusia memiliki hak untuk menentukan pilihannya sendiri, dan pilihan itu diakui secara hukum (Glen, 2015, hlm. 4). Sedangkan dalam pendekatan personal, menurut Quinn, kapasitas hukum juga dianggap mampu membangun konsep martabat diri (personhood) seseorang (2010), sehingga kapasitas hukum dalam penggunaannya dapat diibaratkan sebagai pedang sekaligus tameng atau pelindung. Kapasitas hukum diibaratkan sebagai pedang ketika dapat merefleksikan hak seseorang untuk membuat keputusan sendiri, dan keputusan itu diakui oleh orang lain; sedangkan kapasitas hukum diibaratkan sebagai tameng adalah Ketika digunakan sebagai kekuatan bagi seseorang untuk menghentikan atau menolak orang lain agar tidak mengambil keputusan atas nama dirinya (McSherry, 2012, hlm. 23).

Dalam rujukan hukum internasional, konsep kapasitas hukum sudah tercantum dalam Universal Declaration of Human Rights (UDHR) yang diadopsi sejak 1948. 
Pengadopsian konsep pelindungan terhadap kapasitas hukum dalam UDHR dilakukan sebagai akibat dari pengalaman buruk yang terjadi pada perangduniakedua, yaitupembunuhan masal terhadap 60.000 orang dengan disabilitas intelektual dan mental (Glen, 2015, hlm. 4). Hampir 40 tahun berselang, konsep penghormatan dan pelindungan terhadap kapasitas hukum penyandang disabilitas mental diperkuat dalam CRPD. Penghormatan dan pelindungan terhadap kapasitas hukum dalam CRPD dianggap membawa perubahan paradigma yang radikal, berbasis pada perubahan cara pandang medical model menuju social model dalam pengambilan keputusan (Richardson, 2012, hlm. 351).

Artikel 21 UDHR menyatakan bahwa, "hak pilih yang universal dan sama rata" (United Nations, 2015, Artikel 21). Prinsip itu menjamin semua orang memiliki hak untuk berpartisipasi dalam pemerintahan. Konvensi Internasional itu masih menggunakan subyek "setiap orang", belum khusus menyebutkan penyandang disabilitas. Delapan belas Tahun berselang, pelindungan terhadap hak pilih dikuatan dengan diadposinya ICCPR. Dalam Artikel 2 paragraf 1 ICCPR disebutkan bahwa,

"setiap negara pihak dalam Konvenan ini mengambil langkah untuk menghormati dan memastikan semua individu di wilayahnya dan merujuk kepada yurisdiksinya untuk mengakui hak-hak yang tercantum dalam Konvensi ini, tanpa ada pembedaan, seperta ras, warna kulit, gender, bahasa, kepercayaan, pendapat politik atau hal lainnya, kepemilikan, kelahiran, dan status lainnya" (ICCPR, 1966, Artikel 2 paragraf $1)$.

Sama halnya dengan UDHR, dalam ICCPR penyandang disabilitas tidak disebut secara spesifik sebagai subyek pelindungan. Khusus terkait dengan hak pilih, dalam Artikel 25 huruf b ICCPR disebutkan bahwa,

"Setiap masyarakat harus
memiliki hak dan kesempatan,
tanpa pembedaan yang telah
dijelaskan dalam Artikel 2 dan
pembatasan yang tidak masuk
akal dalam menggunakan hak
memilih dan dipilih dalam
Pemilu yang berkala dengan
hak pilih yang universal dan
setara, harus dilakukan dengan
hak suara yang rahasia,
jaminan terhadap kebebasan
berekspresi dari keinginan
para pemilih" (ICCPR, 1966,
Artikel 25 huruf b).

Pada 1996, Office of the High Commissioner for Human Rights (OHCHR) mengeluarkan Komentar Umum yang memberikan penjelasan terhadap makna dan jangkauan dari Artikel 25 ICCPR tersebut. Paragraf 4 dari Komentar Umum itu menyatakan bahwa:

"Setiap kondisi yang berlaku
untuk pelaksanaan hak yang
dilindungi oleh pasal 25 harus
didasarkan pada kriteria
yang obyektif dan masuk
akal. Misalnya, mewajibkan
usia yang lebih tinggi untuk
pemilihan atau pengangkatan 
jabatan tertentu daripada dilaksanakan untuk setiap warga negara dewasa. Pelaksanaan hak-hak ini tidak boleh ditangguhkan atau dikecualikan kecuali atas dasar yang ditetapkan oleh hukum dan yang obyektif dan wajar. Misalnya, ketidakmampuan mental yang sudah mapan mungkin menjadi dasar untuk menolak hak seseorang untuk memilih atau memegang jabatan" (OHCHR, 1996, paragraf 4).

Berdasarkan

penjelasan tersebut, kondisi disabilitas mental dapat dijadikan alasan untuk menghilangkan hak memilih dan dipilih pada seseorang. Walaupun Komentar Umum itu juga sudah mencantumkan perlunya penetapan secara hukum serta dengan alasan yang obyektif dan wajar, tetapi dalam pelaksanaannya pembatasan hak pilih bagi penyandang disabilitas mental dilakukan secara diskriminatif.

Sepuluh tahun pasca Komentar Umum terhadap Artikel 25 ICCPR, Majelis Umum PBB memberlakukan CRPD yang secara khusus memberikan penghormatan dan pelindungan terhadap hak pilih penyandang disabilitas, termasuk penyandang disabilitas mental. Penghormatan dan pelindungan hak pilih penyandang disabilitas mental tercantum dalam Artikel 29, yang menyebutkan bahwa,

"Negara pihak harus menjamin hak politik penyandang disabilitas dan kesempatan untuk menikmatinya dalam basis persamaan dengan yang lainnya, dengan memastikan penyandang disabilitas dalam secara efektif dan partisipasi penuh dalam kehicupan politik dan publik dalam basis persamaan dengan yang lainnya, secara langsung dan bebas dalam memilih representasi, termasuk hak dan kesempatan untuk penyandang disabilitas untuk memilih dan dipilih" (CRPD, 2006, Artikel 29 huruf a).

Lahirnya Artikel 29 CRPD merupakan koreksi terhadap batasan-batasan bagi penyandang disabilitas mental mendapatkan dan menggunakan hak pilihnya yang muncul berdaarkan Komentar Umum Artikel 25 ICCPR.

Pada 2011, Office of The High Commissioner for Human Rights (OHCHR) melakukan studi tematis tentang partisipasi dalam kehidupan berpolitik dan bermayarakat bagi penyandang disabilitas, yang kemudian ditandai dengan nomor PBB A/HRC/19/36. Pada Paragraf 68 dan 69 studi tematis menegaskan bahwa CRPD menjamin hak penyandang disabilitas untuk memilih dalam Pemilu tanpa pengecualian sama sekali. Paragraf 70 menegaskan pentingnya studi tematis ini karena masih banyak negara-negara yang menolak hak penyandang disabilitas mental untuk memilih dalam Pemilu. Sedangkan pada paragraf 71 studi tematis ini merekomendasikan Dewan HAM merevisi Komentar Umum terkait dengan artikel 25 ICCPR (Human Rights Council, 2011, hlm. 15)

Dewan HAM membahas studi tematis tersebut pada sidang ke-19. Pada laporannya, PBB A/HRC/19/2, 
khususnya pada paragraph 3 keputusan 19/11 menyebutkan bahwa Dewan HAM mengajak negara-negara untuk menelaah penemuan-penemuan dan rekomendasi tersebut. Pada paragraf 7 keputusan 19/11, Dewan HAM mengajak negara peserta konvensi meninjau kembali pengucilan atau larangan yang ada pada hak berpolitik penyandang disabilitas mental atau intelektual, dan untuk mengambil tindakan-tindakan yang layak (Human Rights Council, 2013, hlm. 38).

Dari penjabaran tersebut terlihat bahwa dinamika jaminan penghormatan dan pelindungan hak pilih penyandang disabilitas mental diwarnai dengan perubahan pemaknaan kapasitas hukum penyandang disabilitas mental. Dalam Komentar Umum Artikel 25 ICCPR terlihat penyusunnya ingin menggunakan pendekatan rangkaian proses, dengan mempertimbangkan legal agency dari penyandang disabilitas mental. Namun hal itu tidak berhasil dipahami dalam implementasinya yang masih dominan menggunakan pendekatan Semua atau Tidak Sama Sekali (All or Nothing). Hal itu kemudian berubah ketika Artikel 29 CRPD diberlakukan, yang secara jelas menggunakan pendekatan Universal.

Pasal 12 paragraf 2 CRPD menyebutkan bahwa setiap negara pihak harus mengakui bahwa seluruh penyandang disabilitas dapat menikmati kapasitas hukumnya secara setara dalam seluruh aspek kehidupan (United Nations, 2006, Pasal 12 paragraf 2). CRPD menempatkan kapasitas mental sebagai suatu hasil dari interaksi individu dan lingkungan sosial, sehingga apabila ada hambatan dalam aspek kapasitas mental maka yang harus diubah adalah pola interaksi individu dan lingkungan sosialnya, bukan fokus kepada memperbaiki atau menyembuhkan orangnya (Series, 2015, hlm. 80). Perubahan itu harus dilakukan tanpa mengurangi sedikitpun pengakuan terhadap kapasitas hukum orang tersebut. Dalam paragraf 28 Komentar Umum CRPD, Komite CRPD menegaskan bahwa setiap orang, terlepas dari kondisi disabilitas atau kemampuannya dalam mengambil keputusan, memiliki Kapasitas Hukum (Committee on the Rights of Persons with Disabilities 2014, par. 28). Penjelasan dalam paragraf 28 inilah yang menegaskan bahwa pelaksanaan kapasitas hukum bukanlah hasil dari penentuan kapasitas mental, sehingga kedua konsep ini tidak boleh digabungkan (Barton-Hanson, 2018, hlm. 282).

Dalam Komentar Umum pasal 12 CRPD, Komite CRPD memegaskan bahwa Kapasitas Hukum terdiri dari dua aspek, yaitu legal standing dan legal agency. Legal standing fokus pada aspek formil, yatu melihat penyandang disabilitas sebagai subyek hukum atau pemegang hak secara hukum; sedangkan legal agency melihat pada aspek materiil, yaitu kemampuan penyandang disabilitas untuk menlaksanakan haknya (Committee on the Rights of Persons with Disabilities 2014, par. 13). Bobot dalam melihat masing-masing aspek inilah yang mempengaruhi variasi pendekatan yang berkembang di berbagai literatur dalam memahami konsep kapasitas hukum. Ada tiga pendekatan dalam 
memahami kapasitas hukum berbasis pada legal standing dan legal agency, yaitu pendekatan Seluruhnya atau Tidak Sama Sekali (All or Nothing), pendekatan Universal, dan pendekatan Rangkaian Kesatuan (Continuum) (Browning et al, 2014, hlm. 4).

Pendekatan "Seluruhnya atau Tidak Sama Sekali" (All or Nothing) merupakan pendekatan klasik yang berbasis kepada asumsi atau praduga bahwa setiap orang dengan disabilitas mental pasti tidak memiliki kapasitas hukum. Dalam pendekatan ini tidak sama sekali mempertimbangkan bobot dalam legal standing atau legal agency, karena anggapan dasarnya adalah semua penyandang disabilitas, terutama penyandang disabilitas mental, adalah sama (Browning, Bigby and Douglas, 2014, hlm. 4). Dampak dari pandangan ini adalah penyandang disabilitas tidak diakui kapasitas hukumnya, dan dalam mengambil keputusan atas dirinya dapat diambil alih oleh orang lain.

Pendekatan Universal lebih banyak melihat kepada legal standing dibandingkan legal agency, sehingga argumentasi utamanya lebih melihat pada aspek formil, yaitu setiap orang adalah subyek hukum yang memiliki hak atas kapasitas hukum. Pendekatan ini tidak menekankan kepada kemampuan individu untuk membuat keputusan, tetapi lebih menekankan kepada hak individu untuk membuat keputusan dan dihormati atas keputusannya tersebut (Bach \& Kerzner, 2010, hlm. 18). Cara pandang ini menempatkan kapasitas hukum lebih dari sekadar pengambilan keputusan, tetapi lebih kepada merepresentasikan untuk menjadi manusia seutuhnya (Commissioner for Human Rights, 2012). Pendekatan Universal banyak dipengaruhi oleh sudut pandang filosofis, dibandingkan praktis, dimana kapasitas mental tidak dianggap sebagai kondisi diri seseorang, tetapi hasil dari interaksi sosial dan bersifat kontekstual, yang kemudian berdampak kepada kemampuan seseorang dalam mengambil keputusan (Browning et al, 2014, hlm. 7). Pendekatan Universal lebih banyak digunakan dalam prinsipprinsip umum, baik secara internsional seperti dalam UDHR, ICCPR, dan CRPD; maupun dalam konstitusi suatu negara.

Pendekatan

Rangkaian

Kesatuan atau rangkaian proses berupaya menguatkan kembali pertimbangan terhadap legal agency dibandingkan dengan hanya melihat pada legal standing. Pendekatan ini tetap mengakui bahwa setiap orang adalah subyek hukum, tetapi tidak berhenti disitu karena dalam aspek praktis perlu melihat kepada kemampuan orang tersebut untuk menggunakan haknya, terutama dalam pengambilan keputusan. Pendekatan ini mengakui bahwa kemampuan seseorang dalam melakukan tindakan hukum tidaklah tetap atau statis, tetapi dapat berubah seiring waktu. Hal itu terjadi karena pengaruh dari lingkungan dan pengalaman individu (Browning et al, 2014, hlm. 7). Oleh karena itu, dalam pendekatan ini sangat relevan untuk melakukan penilaian terhadap kapasitas mental seseorang dengan 
mempertimbangkan aspek sosial dan faktor kontekstual lainnya, yang sangat mungkin ada perbedaan antara penilaian terhadap satu orang dengan orang lainnya (Browning et al, 2014, $\mathrm{hlm}$. 7). Hal itu juga yang membedakan dengan jelas pendekatan rangkaian proses dengan pendekatan Semua atau Tidak Sama Sekali (All or Nothing) yang hanya berbasis kepada praduga terhadap status atau label seseorang sebagai seorang penyandang disabilitas, dan menyeragamkan kondisi satu penyandang disabilitas dengan yang lainnya.

Dalam pendekatan rangkaian proses memungkinkan seseorang dinyatakan tidak memiliki kapasitas hukum (Browning et al, 2014, hlm. 7). Namun begitu, untuk sampai menyatakan seseorang tidak memiliki kapasitas hukum, bahkan berdampak kepada pembatasan hak orang tersebut, proses yang dilalui tidak mudah. Selain tidak mudah, proses penilaian juga harus didahului dengan serangkaian aktivitas untuk mendukung orang tersebut dapat mengambil keputusan secara mandiri, yang dikenal dengan supported Decision Making. Hal itu juga yang membedakan dengan pendekatan Semua atau Tidak Sama Sekali, yang langsung mengambilalih pengambilan keputusan atas diri seorang penyandang disabilitas atau dikenal dengan substituted decision making (Browning et al, 2014, hlm. 7).

\section{Hasil Pembahasan}

Pelindungan hak pilih penyandang disabilitas menjadi salah satu isu kepemiluan yang mengemuka dalam beberapa tahun terakhir, terutama pasca disahkannya CRPD pada 2006. CRPD membuka pandangan banyak pihak bahwa masih ada kelompok masyarakat yang mengalami hambatan dalam memiliki dan menggunakan hak pilihnya. Berbagai upaya dilakukan untuk memberikan jaminan pelindungan hak pilih penyandang disabilitas di Indonesia. Namun upaya yang dilakukan masih banyak fokus pada disabilitas dengan hambatan mobilitas dan sensorik, baik penglihatan atau pendengaran, dengan penyediaan aksesibilitas berupa fasilitas atau pelayanan. Sedangkan bagi penyandang disabilitas mental, permasalahan yang dihadapi lebih mendalam dari sekadar penyediaan fasilitas atau pelayanan, tetapi harus dimulai dari mengubah cara pandang terhadap kapasitas hukum penyandang disabilitas mental.

Dinamika jaminan pelindungan hak pilih penyandang disabilitas mental sudah terjadi di tingkat internasional, nasional, sampai regional. Dalam bagian ini akan dianalisa bagaimana dinamika penguatan pelindungan hak pilih penyandang disabilitas mental di Indonesia dengan menganalisa pendekatan kapasitas hukum yang digunakan dalam Putusan MK 135. Pembahasan itu akan menjadi basis dalam menjawab bagaimana seharusnya Putusan MK 135 diadaptasi dalam berbagai peraturan pelaksanaan dalam mengatur tahapan-tahapan dalam Pemilu/Pilkada.

$$
\text { Analisa yang dilakukan }
$$
juga akan mempertimbangkan permasalahan-permasalahan yang masih timbul terkait dengan jaminan pelindungan hak pilih penyandang 
disabilitas mental di lapangan setelah 4 tahun keberlakuan Putusan MK 135, dan sudah melewati dua kali Pilkada pada 2017 dan 2018, serta satu kali Pemilu pada 2019.

\subsection{Analisa Pendekatan Kapasitas Hukum Penyandang Disabilitas Mental dalam Putusan MK 135}

Putusan MK 135 membawa kemajuan terhadap upaya pelindungan hak pilih bagi penyandang disabilitas. Dengan menyatakan bahwa syarat "tidak sedang terganggu jiwa/ ingatannya" untuk terdaftar sebagai pemilih dalam Pilkada inkonstitusional, maka secara tidak langsung MK juga mengakui bahwa penyandang disabilitas mental memiliki legal standing sebagai pemegang hak pilih, sehingga harus dapat tercatat dalam daftar pemilih. Selain legal standing, Putusan MK 135 juga menilai kapasitas hukun dari aspek legal agency, yaitu kemampuan pemilih dalam menggunakan hak pilihnya.

Pada Pertimbangan Hukum paragraf 3.17 Putusan MK 135 disebutkan bahwa,

"Menimbang bahwa di hadapan hukum terutama dalam kaitannya dengan hak untuk memilih dan hak untuk terdaftar dalam daftar pemilihan, yang mengasumsikan adanya kemampuan membuat pilihan, masing-masing kategori gangguan jiwa dan/atau gangguan ingatan sebagaimana diuraikan di atas tidak boleh diperlakukan secara sama. ... “

Selain itu, dalam pertimbangan hukum 3.21 angka 4, MK juga menyebutkan bahwa,

"tidak semua orang yang
sedang mengalami gangguan
jiwa dan/atau gangguan
ingatan akan kehilangan
kemampuan untuk menjadi
pemilih dalam pemilihan
umum."

Dari kedua pertimbangan hukum tersebut terlihat bahwa MK sepakat bahwa setiap orang memiliki kemampuan yang berbeda dalam membuat pilihan atau mengambil keputusan, termasuk orang-orang yang sedang terganggu jiwa/ingatannya.

Pengakuan terhadap adanya perbedaan kemampuan tersebut menunjukanbahwaMKtidakmenganut pendekatan "Semua atau Tidak Sama Sekali" dalam memandang kapasitas hukum penyandang disabilitas. Hal itu sudah sejalan dengan prinsip-prinsip HAM, baik yang tercantum dalam Artikel 25 ICCPR maupun Artikel 29 CRPD, yaitu jaminan pelindungan hak pilih penyandang disabilitas mental.

Selain itu, ada hal lain yang perlu dianalisa dalam pertimbangan hukum Putusan MK 135, khususnya dalam menerapkan penilaian pada aspek legal agency. Dalam pertimbangan hukum 3.17.1, MK menyatakan bahwa, “... Dibutuhkan keahlian (profesi) tertentu untuk dapat dengan tepat menilai seseorang sedang terganggu jiwa dan/atau ingatannya.", dan “... Ketiadaan pedoman serta lembaga yang tepat untuk menjalankan ketentuan Pasal 57 ayat (3) huruf a 
berpotensi menimbulkan pelanggaran terhadap hak konstitusional calon pemilih untuk terdaftar sebagai calon pemilih.". Di satu sisi pertimbangan dalam Putusan MK ini menegaskan bahwa MK sejalan dengan pendekatan "Continuum", yaitu dalam pelaksanaan hak tetap memerlukan penilaian akan kemampuan dari pemegang hak. Namun, di sisi lain kedua pertimbangan itu tidaklah kontekstual dengan lingkup norma yang sedang diuji.

Putusan MK 135 disusun atas permohonan uji materiil terhadap Pasal yang mengatur terkait dengan pendaftaran pemilih dalam Pilkada. Untuk masuk dalam daftar pemilih Pilkada belumlah perlu untuk mempertimbangkan apakah orang yang terdaftaritu memiliki kemampuan mengambil keputusan (legal agency) atau tidak karena masih adanya jarak waktu antara pendaftaran pemilih dengan pemungutan suara, yang masih memungkinkan segala hal terjadi, termasuk kesembuhan bagi yang sebelumnya dianggap tidak mampu mengambil keputusan, atau justru sakit atau kecelakaan yang membuat seseorang kehilangan kemampuannya untuk mengambil keputusan. Selain itu, keberadaan pedoman untuk menilai seseorang mampu mengambil keputusan atau tidak oleh ahli, untuk masuk dalam daftar pemilih, hanya akan memperpanjang birokrasi, dan menambah beban kerja KPU, tetapi hasil pekerjaannya masih berpotensi tinggi untuk berubah, baik disengaja atau tidak disengaja.

Sehingga kehadiran Putusan MK 135 menjadi sumbangsih penting bagi pengakuan hak memilih penyandang disabilitas dalam penyelenggaraan Pemilu dan Pilkada, dengan harapan kedepan sudah tidak ada lagi yang mempersoalkan keikutsertaan penyandang disabilitas menjadi pemilih dalam Pemilu dan Pilkada.

\subsection{Advokasi Implementasi Putusan MK 135 dalam Penyelenggaraan Pilkada dan Pemilu}

Terlepas dari kritik tersebut, Putusan MK 135 tetap bermanfaat sebagai pintu masuk untuk membentuk kebijakan lanjutan terkait dengan pelindungan hak pilih penyandang disabilitas mental. Pasca Putusan MK 135 terjadi sejumlah perubahan regulasi untuk menyesuaikan dengan Putusan MK tersebut. Namun perubahan itu tidak terjadi begitu saja, tetapi ada andil dari perjuangan advokasi organisasi penyandang disabilitas, terutama dalam memberikan pemahaman dan menjabarkan situasi yang terjadi di lapangan. Perubahan regulasi tidak langsung terjadi, bahkan ada beberapa diantaranya yang baru berubah setelah didesak oleh organisasi penyandang disabilitas.

Putusan MK 135 terbukti membawa hal positif dalam pelaksanaan Pilkada dan Pemilu, yang terkonfirmasi langsung oleh para penyelenggara Pemilu/Pilkada. Menurut Anggota KPU RI, I Dewa Kade Wiarsa Raka Sandi menyampaikan bahwa, "Putusan MK 135 juga memperkuat pelaksanaan kedaulatan rakyat melalui praktik Pemilu/Pilkada, dimana dalam pelaksanaannya 
termanifestasikan dalam hak pilih warga negara" (Sandi, 2020).

Nur Kholis Madjid, Anggota Bawaslu Kalimantan Selatan, menyampaikan bahwa Putusan MK 135 membuat pemahaman lebih jelas mengenai kondisi gangguan jiwa dan hak memilih (Madjid, 2020). Sedangkan menurut Nurul Amalia, Anggota KPU Provinsi Jawa Timur, berpendapat bahwa, "Putusan MK 135 membantu dalam menjustifikasi syarat-syarat bagi pemilih dari penyandang disabilitas mental, karena pada awalnya bingung mana yang harus pakai surat dokter dan mana yang tidak, yang berdampak kepada perdebatan di lapangan" (Amalia, 2020). Kedua pendapat itu menggambarkan bahwa ada kesulitan ketika syarat itu masih ada berdasarkan ketentuan dalam pasal 57 ayat (3) huruf a UU 8/2015, yaitu menjustifikasi kondisi jiwa/ingatan seseorang, yang dapat berdampak kepada tidak terdaftar sebagai pemilih, yang menurut MK dalam Putusan 135 dapat berdampak kepada hilangnya hak pilih orang tersebut.

Purnomo S. Pringgodigdo, Anggota Bawalu Provinsi Jawa Timur, dalam wawancara dengan penulis menyampaikan bahwa, "Di tingkat daerah Putusan MK 135 berpengaruh karena ada perintah dari pusat" (Pringgodigeto, 2020). Hal itu juga diakui oleh narasumber lain yang berasal dari lembaga penyelenggara Pemilu/Pilkada di tingkat daerah, sehingga membuktikan bahwa sikap dari KPU RI dan Bawaslu RI akan sangat menentukan implementasi dari suatu Putusan MK yang terkait dengan kepemiluan. Namun begitu, sikap responsif dari KPU RI dan Bawaslu RI tidak dapat dipisahkan dari aktifnya organisasi penyandang disabilitas mental dalam melakukan advokasi, terutama mendesak KPU $\mathrm{RI}$ dan Bawaslu RI untuk segera mengeluarkan sejumlah peraturan pelaksanaan merespon Putusan MK 135 tersebut.

Dampak positif Putusan MK 135 tidak terlepas dari advokasi yang dilakukan oleh jaringan organisasi penyandang disabilitas, khususnya organisasi penyandang disabilitas mental. Yeni Rosa Damayanti, Ketua Perhimpunan Jiwa Sehat (PJS), menyampaikan bahwa upaya advokasi sudah dilakukan seiring dengan proses uji materi terhadap Pasal 57 ayat (3) huruf a UU 8/2015 (2020). Pada saat itu hasil dari advokasi organisasi penyandang disabilitas, KPU RI mengeluarkan Surat Edaran KPU RI Nomor 7 tahun 2016 tentang Penyampaian Formulir Alat Bantu Periksa Pelaksanaan Pemilih Akses bagi Pemilih Penyandang Disabilitas (selanjutnya disebut SE 7/2016). SE $7 / 2016$ dibentuk berdasarkan UU 8/2016, dan pada saat itu Putusan MK 135 belum keluar.

\section{Dalam SE 7/2016 tertulis} keharusan melakukan identifikasi pemilih penyandang disabilitas dalam daftar pemilih tetap, dan pemutakhiran data dan daftar pemilih, yang kemudian menjadi pintu masuk bagi organisasi penyandang disabilitas memastikan penyandang disabilitas mental masuk atau terdaftar dalam daftar pemilih tetap. Pelaksanaan SE 7/2016 tidak dapat maksimal karena disahkan ditengah proses yang sedang berjalan, dan ada temuan 
bahwa tidak semua KPUD membaca dan memahami isi SE 7/2016 itu, sehingga ditemukan rumah sakit jiwa dan panti yang tidak mendaftarkan penghuninya sebagai pemilih dalam Pilkada 2017 (Damayanti, 2020).

\section{Putusan MK 135 diadopsi} dalam Undang-Undang Nomor 7 Tahun 2017 tentang Pemilihan Umum (UU 7/2017). Dalam UU itu sudah tidak ada lagi syarat tidak sedang terganggu jiwa/ingatannya untuk menjadi pemilih, dan penyandang disabilitas dijamin sebagai pemilih dalam Pasal 5 yang menyebutkan bahwa:

"Penyandang disabilitas yang memenuhi syarat mempunyai kesempatan yang sama sebagai Pemilih, sebagai calon anggota DPR, sebagai calonn anggota DPD, sebagai calon Presiden/Wakil Presiden, sebagai calon anggota DPRD, dan sebagai penyelenggara Pemilu."

Pada Pasal 198 UU 7/2017 yang khusus mengatur perihal hak pilih tidak menyinggung terkait dengan syarat "tidak sedang terganggu jiwa/ ingatannya" untuk masuk dalam daftar pemilih, karena syarat hanya mencakup warga negara Indonesia yang pada hari pemungutan suara sudah genap 17 tahun atau lebih, sudah kawin, atau sudah pernah kawin (Pasal 192 ayat (1) UU 7/2017). Begitupun dalam ketentuan di Bab $\checkmark$ UU 7/2017 tentang penyusunan daftar pemilih disebutkan bahwa daftar pemilih disusun berdasarkan data administrasi kependudukan yang dimutakhirkan, yang pelaksanaannya terbuka atas masukan dari masyarakat.
Pasca pergantian Anggota KPU RI untuk periode 2017-2022, advokasi terkait dengan pelindungan hak pilih penyandang disabilitas mental berdasarkan Putusan MK 135 mengalami kemunduran. Hal itu dapat terlihat dari substansi Peraturan KPU Nomor 11 Tahun 2018 tentang Penyusunan Daftar Pemilih di Dalam Negeri dalam Penyelenggaraan Pemilihan Umum (PKPU 11/2018). Dalam Pasal 4 ayat (2) huruf $b$, ayat (3), dan ayat (4) PKPU 11/2018 mencantumkan kembali syarat "tidak sedang terganggu jiwa/ingatannya" untuk terdaftar sebagai pemilih.

PKPU 11/2018 mendapat tentangan keras dari PJS yang mewakili organisasi penyandang disabilitas mental, dan mendesak KPU untuk melakukan revisi. Desakan itu direspon positif oleh KPU, dan untuk merealisasikannya PJS dan koalisi organisasi penyandang disabilitas melakukan lobi kepada fraksi-fraksi di DPR untuk menyetujui juga usulan revisi tersebut (Damayanti, 2020). KPU RI akhirnya membentuk PKPU Nomor 37 Tahun 2018 tentang Perubahan atas Peraturan Komisi Pemilihan Umum Nomor 11 Tahun 2018 tentang Penyusunan Daftar Pemilih di Dalam Negeri dalam Penyelenggaraan Pemilihan Umum (PKPU 37/2018). PKPU 37/2018 menghapus beberapa ketentuan termasuk menghapus ketentuan Pasal 4 ayat (2) huruf b dan ayat (3) PKPU 11/2018.

Dalam konteks Pilkada, pengaturan terkait hak memilih penyandang disabilitas mental memiliki dinamika tersendiri. Pasca hadirnya Putusan MK 135, KPU tidak langsung menerapkannya kepada 
peraturan pelaksanaan Pilkada yang dibentuk. Pada PKPU Nomor 2 Tahun 2017 tentang Pemutakhiran Data dan Penyusunan Daftar Pemilih dalam Pemilihan Gubernur dan Wakil Gubernur, Bupati dan Wakil Bupati, dan/atau Walikota dan Wakil Walikota (PKPU 2/2017) masih menempatkan syarat "tidak sedang terganggu jiwa dan/atau ingatannya" untuk terdaftar sebagai Pemilih. Penyesuaian terhadap Putusan MK 135 baru dilakukan pada saat membentuk PKPU Nomor 19 Tahun 2019 tentang Perubahan atas Peraturan KPU Nomor 2 Tahun 2017 tentang Pemutakhiran Data dan Penyusunan Daftar Pemilih dalam Pemilihan Gubernur dan Wakil Gubernur, Bupati dan Wakil Bupati, dan/atau Walikota dan Wakil Walikota (PKPU 19/2019), yang menghapus syarat "tidak sedang terganggu jiwa dan/atau ingatannya" tersebut. Hal itu memberi andil belum maksimalnya pelaksanaan Putusan MK 135 dalam konteks Pilkada.

\subsection{Permasalahan Implementasi Pelindungan Hak Pilih Penyandang Disabilitas Mental Pasca Putusan MK Nomor 135/PUU-VIII/2015}

Dampak positif Putusan MK 135 terhadap perubahan perspektif pembentuk kebijakan dalam melihat hak pilih penyandang disabilitas mental, ternyata belum diikuti implementasinya di lapangan. Menurut Anggota KPU RI, I Dewa Kade Wiarsa Raka Sandi, kebijakan memasukan penyandang disabilitas mental dalam daftar pemilih juga banyak dipertanyakan oleh kelompok masyarakat, muncul tuduhan keberpihakan dari penyelenggara Pemilu/Pilkada, apalagi jika hasil penghitungan suara berselisih tipis (Sandi, 2020). Nurul Amalia, Anggota KPU Jawa Timur, menyepakati hal itu, tetapi menyampaikan bahwa kritik atau tuduhan itu tidak pernah dapat dibuktikan dan dalam pelaksanaannya, penghitungan suara selalu dihadiri oleh saksi dari masingmasing peserta Pemilu/Pilkada. Kondisi itu menunjukan bahwa stigma negatif terhadap penyandang disabilitas mental masih menjadi basis untuk menkritik kebijakan memasukan penyandang disabilitas mental sebagai pemilih.

Selain hal

tersebut, permasalahan lain yang terjadi dalam pemenuhan hak pilih penyandang disabilitas mental adalah belum tercatatnya dalam administrasi kependudukan, atau perbedaan antara lokasi tinggal dengan domisili dari KTP yang bersangkutan (Damayanti, 2020). Kondisi itu banyak ditemukan di rumah sakit jiwa atau panti-panti yang menampung penyandang disabilitas mental. Secara teknis, permasalahan itu dapat diselesaikan dengan menghubungi KPUD dan dinas kependudukan dan catatan sipil setempat, tetapi karena kondisi para penyandang disabilitas mental yang kerap terisolir di rumah sakit jiwa atau panti, maka sulit untuk melakukannya. Dilain pihak, petugas rumah sakit dan panti tidak memberikan dukungan dalam mengurusi hal tersebut.

Permasalahan lainnya adalah adanya keengganan dari keluarga, kerabat, atau masyarakat sekitar untuk mengupayakan pelindungan hak pilih bagi penyandang disabilitas 
mental. Nur Kholis Madjid, Anggota Bawaslu Kalimantan Selatan, menyampaikan bahwa ada upaya dari keluarga untuk menyembunyikan anggota keluarganya yang merupakan penyandang disabilitas mental (2020). Rasa malu dan khawatir melakukan Tindakan yang tidak terkontrol menjadi alasan utama dari keluarga tersebut. Selain itu, penyandang disabilitas mental kerap tidak terdaftar dan kemudian tidak menggunakan hak pilihanya adalah karena terisolasi di rumah sakit jiwa atau panti. Kondisi itu dilakukan biasanya berbasis kepada keputusan petugas panti, atau surat hasil pemeriksaan dari dokter atau psikiater, tetapi tidak dilakukan secara maksimal dan orang per orang (Damayanti, 2020).

$$
\text { Kebijakan }
$$

mengisolasi

penyandang disabilitas mental dalam rumah sakit jiwa atau panti berdasar kepada pemahaman bahwa seorang dengan disabilitas mental tidak memiliki kapasitas hukum. Fenomena itu menkonfirmasi pendekatan "Semua atau Tidak Sama Sekali" untuk menilai kapasitas hukum seorang penyandang disabilitas mental. Dalam pendekatan ini, status atau label sebagai penyandang disabilitas mental menjadi dasar untuk orang lain mengambil alih pengambilan keputusan atas dirinya, atau dikenal sebagai substitute decision making. Padahal dalam Pasal 436-446 Kitab Undang-Undang Hukum Perdata menyebutkan bahwa seseorang berada dalam pengampuan adalah hasil dari penetapan pengadilan yang bersifat individual, untuk tujuan tertentu, dan dengan hukum acara yang jelas (Susanti, 2016). Oleh karena itu, status pengampuan atau bahkan sampai kehilangan kapasitas hukum tidak dapat dilakukan secara sembarangan dan sepihak.

\subsection{Jaminan Pelindungan Hak Pilih Penyandang Disabilitas dalam Pemilu/Pilkada dengan Pendekatan Rangkaian Proses}

Putusan MK 135 sudah menyatakanbahwasyarat "tidaksedang terganggu jiwa/ingatannya", untuk masuk dalam daftar pemilih dalam Pilkada, inkonstitusional. Putusan itu disusun dengan membangun dan memperkenalkan pemahaman baru akan kapasitas hukum penyandang disabilitas mental. Putusan MK 135 menggunakan pendekatan rangkaian proses dalam menganalisa kapasitas hukum penyandang disabilitas mental. Dengan pendekatan itu, MK tidak hanya mempertimbangkan legal standing penyandang disabilitas mental sebagai seorang manusia yang harus diakui kapasitas hukumnya, MK juga melihat kepada aspek legal agency dalam menentukan kapasitas hukum penyandang disabilitas mental, yaitu melihat kemampuan untuk memiliki dan menggunakan hak pilihnya.

Dalam pendekatan rangkaian proses, seorang penyandang disabilitas satu dengan yang lainnya memliki kemampuan pengambilan keputusan yang berbeda, sehingga perlu ada penilaian orang per orang untuk menentukan kemampuan pengambilan keputusannya. Dalam konteks hak pilih, maka orang dengan disabilitas mental dapat dinilai seberapa mampu untuk memiliki atau menggunakan hak pilihnya. 
Walaupun begitu, berbeda dengan pendekatan "Semua atau Tidak Sama Sekali", yang lebih mudah menentukan seseorang dengan disabilitas mental tidak memiliki kapasitas hukum sehingga tidak mempunyai hak pilih. Misalnya setiap orang yang berada dalam panti, rumah sakit jiwa, atau tempat pengobatan gangguan jiwa lainnya dianggap tidak memiliki kapasitas hukum, sehingga tidak perlu didaftar sebagai pemilih. Terlebih dengan statusnya itu segala keputusan yang menyangkut dirinya dapat diambilalih oleh orang lain (substitute decision making).

Dalam pendekatan rangkaian proses, penilaian kapasitas hukum orang dengan disabilitas mental harus berdasar kepada pengakuan atas statusnya sebagai pemegang hak pilih. Selanjutnya, perlu penilaian dari ahli untuk menentukan tingkat kemampuan orang dengan disabilitas mental dalam mengambil keputusan atas hak pilihnya. Penilaian ini harus dilakukan orang per orang dengan tetap mengutamakan persetujuan dan preferensi pribadi dari penyandang disabilitas mental tersebut. Penilaian yang dilakukan akan menghasilkan informasi dukungan apa yang diperlukan agar orang tersebut dapat mengambil keputusannya sendiri atas hak pilihnya.

Dukungan dalam pengambilan keputusan (Supported Decision Making) ini harus berdasar kepada persetujuan atau bahkan permintaan dari orang yang akan didukung, sehingga tidak dapat dipaksakan. Bentuk dukungan dalam hal tersebut diperlukan untuk membantu penyandang disabilitas mental memahami situasi dan kondisi, informasi, atau hanya sekadar teman diskusi, sampai akhirnya dapat mengambil keputusan sendiri secara mandiri. Namun tidak sampai kepada pengarahan kepada salah satu calon tertentu.

Pendekatan

tersebut

harus diadaptasikan kepada teknis pelaksanaan dalam tahapan di Pemilu/Pilkada, khususnya dalam tahap pendaftaran pemilih sampai pemungutan suara. Pada tahap pendaftaran pemilih, sesuai dengan Putusan MK 135, dilarang untuk menerapkan syarat "tidak terganggu jiwa/ingatannya". Oleh karena itu, KPU dan KPUD harus mendaftar setiap orang yang memenuhi syarat, yaitu warga negara Indonesia yang pada hari pemungutan suara sudah genap 17 tahun atau lebih, sudah kawin, atau sudah pernah kawin, termasuk penyandang disabilitas mental dimanapun dan bagaimanapun kondisinya pada saat pendaftaran pemilih dilakukan. Dalam tahap pendaftaran pemilih belum perlu untuk menilai legal agency atau kemampuan seseorang untuk menggunakan hak pilihnya, karena dalam tahap ini pemilih belum akan menentukan pilihannya.

Setelah masuk dalam daftar pemilih, KPU dan KPUD perlu melakukan identifikasi awal calon pemilih yang merupakan penyandang disabilitas mental. Proses identifikasi ini pada dasarnya tidak mudah dilakukan mengingat disabilitas mental tidak terlihat secara fisik. Dalam praktiknya penyandang disabilitas mental yang teridentifikasi adalah mereka yang sedang berada di panti, 
rumah sakit jiwa, atau tempat-tempat pengobatan gangguan jiwa lainnya. Terhadap para penyandang disabilitas mental itu dilakukan penilaian secara orang per orang, dengan tujuan untuk mengetahui dukungan apa saja yang diperlukan agar pada saat pemungutan suara dapat mengambil keputusan secara mandiri, bukan untuk menghakimi bahwa yang bersangkutan penyandang disabilitas mental sehingga tidak memiliki hak pilih. Apabila penyandang disabilitas mental yang bersangkutan sudah setuju untuk mendapatkan dukungan tersebut, maka pemberian dukungan dilakukan dalam periode waktu sebelum pemungutan suara.

Untuk dapat menjalankan pendekatan rangkaian proses dalam pelaksanaan Pemilu/Pilkada, KPU harus menyusun pedoman yang terkait dengan mengidentifikasi pemilih penyandang disabilitas mental, proses penilaian penentuan kebutuhan dukungan secara perorangan, dan proses pemberian dukungan secara perorangan. Selain itu, demi menghadirkan kepastian hukum, maka kepada pihak-pihak yang menghambat pelaksanaan tugas KPU dalam menjalankan pedoman itu masuk dalam kategori menghalang-halangi seseorang yang akan melakukan haknya untuk memilih, sesuai dengan Pasal 531 Undang-Undang Nomor 7 Tahun 2017 tentang Pemilihan Umum, dengan ancaman hukuman pidana penjara paling lama 2 tahun dan denda paling banyak $\mathrm{Rp}$ 24.000.000,00. Tentu dalam pelaksanannya tidak mengedepankan penghukuman terhadap penyelenggara Pemilu/ Pilkada tetapi mendahulukan kepada penguatan pemahaman dan fasilitas pendukung, agar konsep supported decision making dapat dilaksanakan. Selain itu, KPU dan KPUD juga perlu untuk mengalokasikan anggaran untuk memberikan dukungandukungan, seperti penyediaan ahli yang melakukan penilaian kebutuhan dukungan, pemberian dukungan pendampingan, pelaksanaan sosialisasi dan edukasi terkait dengan kepemiluan kepada para penyandang disabilitas mental.

\section{Kesimpulan}

Penghormatan

dan pelindungan terhadap hak pilih penyandang disabilitas mental ditentukan oleh bagaimana kapasitas hukum dari penyandang disabilitas mental diakui, baik dalam aspek legal standing maupun legalagency. Putusan MK 135 sudah membuka pandangan baru dalam mengakui kapasitas hukum penyandang disabilitas mental, yaitu dengan menggunakan pendekatan rangkaian proses, yang tidak hanya mempertimbangkan bahwa seseorang memiliki hak pilih (legal standing), tetapi juga mempertimbangkan kemampuan orang itu dalam mengambil keputusan dalam menggunakan hak pilihnya (legal agency). Pendekatan rangkaian proses ini juga sudah harus diadaptasi dalam praktik kepemiluan di Indonesia, terutama sebagai pelaksanaan dari Putusan MK 135. Penyesuaian harus dilakukan pada tahapan pendaftaran, kampanye, sampai kepada pemungutan suara.

Adapun 3 hal yang harus dilakukan oleh KPU dan KPUD dalam 
mengadaptasi pendekatan rangkaian proses ini, yaitu pertama tetap melakukan pendaftaran kepada setiap penduduk yang memenuhi syarat sebagai pemilih, termasuk para penyandang disabilitas mental. Kedua, melakukan penilaian terhadap orang per orang penyandang disabilitas mental yang terdaftar, untuk mengetahui dukungan apa yang perlu diberikan oleh penyelenggara Pemilu/ Pilkada agar orang tersebut tetap dapat menggunakan hak pilinnya pada waktu pengambilan suara. Bentuk dukungan ini diberikan atas persetujuan penyandang disabilitas mental yang bersangkutan dan tetap memasukan opsi untuk yang bersangkutan tidak menggunakan hak pilihnya atas pikilannya sendiri. Ketiga, menindak setiap orang yang tidak melaksanakan dukungan kepada penyandang disabilitas mental untuk mengambil keputusan secara mandiri sebagai bentuk dari menghalanghalangi seseorang yang akan melakukan haknya untuk memilih. Selain itu, perlu ada alokasi anggaran untuk pelaksanaan dukungandukungan yang dibutuhkan oleh penyandang disabilitas mental dalam melaksanakan hak pilihnya. 


\section{DAFTAR PUSTAKA}

\section{Artikel, Buku dan Jurnal}

Anggono, Bayu Dwi dkk. (2019). Peran Progresif Mahkamah Konstitusi dalam Melindungi Hak Pilih Disabilitas Kategori Orang Dengan Gangguan Jiwa dan Pengaruhnya Terhadap Peningkatan Partisipasi Pemilih dalam Pemilu. Diakses dari: https://www.mkri.id/index.php?page=download. Penelitian\&id=105

Bach, M. \& Kerzner, L. (2010). A new paradigm for protecting autonomy and the right to legal capacity. Diakses dari : http://www.lco-cdo.org/en/ disabilities-call-for-papers-bach-kerzner.

Barton-Hanson, Renu. (2018). Reforming Best Interests: The Road Towards Supported Decision Making. Journal of Social Welfare and Family Law, 40 (3). hlm. 277-298.

Browning, M., Bigby, C., \& Douglas, J., (2014). Supported Decision Making: Understanding How its Conceptual Link to Legal Capacity is Influencing the Development of Practice. http://dx.doi.org/10.1080/23297018.201 4.902726

Commissioner for Human Rights. 2012. Who Gets to Decide? Right to Legal Capacity for Persons with Intellectual and Psychosocial Disabilities. Strasbourg, Perancis: Council of Europe.

Committee on the Rights of Persons with Disabilities. (2014). General Comment Number 1 Article 12: Equal Recognition Before the Law. Diakses dari: https://www.ohchr.org/en/hrbodies/crpd/pages/gc.aspx

Glen, Kristin Booth. (2015). Supported Decision-Making and the Human Right of Legal Capacity. Inclusion, Vol. 3 No. 1, hlm. 2-16. DOI: 10.1352/23266988-3.1.2

Human Rights Council. (2013). Report of the Human Rights Council on its nineteenth session. Diakses dari : https://www.ohchr.org/EN/HRBodies/ HRC/RegularSessions/Session19/Pages/19RegularSession.aspx

Human Rights Council. (2011). Thematic study by the Office of the United Nations High Commissioner for Human Rights on participation in political and public life by persons with disabilities. Diakses dari: https://www.ohchr. org/Documents/HRBodies/HRCouncil/_RegularSession/Session19/AHRC-19-36 en.pdf

Istanto, F. Sugeng. (2007). Penelitian Hukum. Yogyakarta, Indonesia: CV Ganda. 
Lembaga Bantuan Hukum Masyarakat. (2020). Asesmen Hukum Pengampuan Indonesia: Perlindungan Hak Orang dengan Disabilitas Psikososial. Diakses dari : https://lbhmasyarakat.org/wp-content/uploads/2020/10/ Asesmen-Hukum-Pengampuan-Indonesia LBHM.pdf

Marzuki, P.M. (2006). Penelitian Hukum. Jakarta. Kencana.

McSherry, Bernadette. (2012). Legal Capacity Under the Convention on the Rights of Persons with Disabilities. Journal pf Law and Medicine, September 2012. Diakses dari : https://www.researchgate.net/ publication/266798062 Legal Capacity Under the Convention on the Rights of Persons with Disabilities

Rahmanto, Tony Yuri. (2019). Hak Pilih Bagi Penyandang Disabilitas Mental Ditinjau dari Perspektif Hak Asasi Manusia. Diakses dari : file:///D:/ MyDocu/Downloads/570-3052-3-PB.pdf

Series, Lucy. (2015). Relationships, Autonomy and Legal Capacity: Mental Capacity and Support Paradigms. International Journal of Law and Psychiatry, Vol. 40, hlm. 80-91. https://doi.org/10.1016/j.ijlp.2015.04.010

Quinn, G. (2010, Februari). Personhood \& legal capacity: Perspectives on the paradigm shift of Article 12. Diakses dari http://www.nuigalway.ie/cdlp/ documents/publications/Harvard\% 20Legal\%20Capacity\%20gq\%20 draft\%202.doc

Richardson, G.. (2012). Mental Disabilities and the Law: From Substitute to Supported. Current Legal Problems, Vol. 65, hlm. 333-354. doi:10.1093/ clp/cus010

Sumardjono, Maria S.W. (1989). Pedoman Pembuatan Usulan Penelitian. Yogyakarta, Indonesia: Fakultas Hukum UGM. Yogyakarta.

Susanti, Bivitri. (2016). Hak Memilih Untuk Warga Negara Penyandang Disabilitas Mental dan Intelektual. Disampaikan pada Sidang Pengujian Pasal 57 ayat (3) huruf a UU 8/2015, 4 April 2016.

United Nations. (1966). International Convenant on Civil and Political Rights. Diakses dari https://treaties.un.org/doc/publication/unts/volume\%20 999/volume-999-i-14668-english.pdf

United Nations. (2015). Universal Declaration of Humarn Rights. Diakses dari https://www.un.org/en/udhrbook/pdf/udhr booklet en_web.pdf

United Nations. 2006. Convention on the Rights of Persons with Disabilities. Diakses dari : https://www.un.org/disabilities/documents/convention/ convoptprot-e.pdf 


\section{Wawancara}

Amalia, Nurul. 2020. Wawancara diselenggarakan pada 20 Juli 2020 secara online.

Damayanti, Yeni Rosa. 2020. Wawancara diselenggarakan pada 31 Juli 2020 secara online.

Madjid, Nur Kholis. 2020. Wawancara diselenggarakan pada 16 Juli 2020 secara online.

Pringgodigdo, Purnomo S. Wawancara diselenggarakan pada 20 Juli 2020 secara online.

Sandi, I Dewa Kade Wiarsa Raka. 2020. Wawancara diselenggarakan pada 22 Juli 2020 secara online.

\section{Putusan Mahkamah Konstitusi dan Peraturan Perundang-undangan}

Undang-Undang Nomor 7 Tahun 2017 tentang Pemilihan Umum.

Undang-Undang Nomor 8 Tahun 2016 tentang Penyandang Disabilitas

Undang-Undang Nomor 8 Tahun 2015 tentang Perubahan Atas Undang-Undang

Nomor 1 Tahun 2015 tentang Penetapan Peraturan Pemerintah

Pengganti Undang-Undang Nomor 1 Tahun 2014 tentang Pemilihan

Gubernur, Bupati, dan Walikota Menjadi Undang-Undang.

Undang-Undang Nomor 19 Tahun 2011 tentang Retifikasi Konvensi Hak Penyandang Disabilitas.

Undang-Undang Nomor 12 Tahun 2005 tentang Ratifikasi Konvensi Hak Sipil dan Politik.

Kitab Undang-Undang Hukum Perdata.

Putusan Mahkamah Konstitusi Nomor 135/PUU-VIII/2015.

\section{Website}

https://www.ncsbe.gov/voting/help-voters-disabilities, diakses pada 5 November 2020.

https://www.sos.alabama.gov/alabama-votes/voter/assistance-disability, diakses pada 5 November 2020.

https://www.disabilityrightswa.org/publications/assisting-voters-disabilities/, diakses pada 5 November 2020.

https://www.aec.gov.au/assistance, diakses pada 5 November 2020. 